\title{
Clinical Approach of High Technology Techniques for Control and Elimination of Endodontic Microbiota
}

\author{
Nasim Chiniforush ${ }^{1+}$, Maryam Pourhajibagher ${ }^{2+}$, Sima Shahabi ${ }^{3}$, Abbas Bahador ${ }^{2 *}$ \\ ${ }^{1}$ Laser Research Center of Dentistry (LRCD), Dental Research Institute, Tehran University of Medical Sciences, \\ Tehran, Iran \\ ${ }^{2}$ Department of Microbiology, School of Medicine, Tehran University of Medical Sciences, Tehran, Iran \\ ${ }^{3}$ Dental Biomaterials Department, School of Dentistry, Tehran University of Medical Sciences, Tehran, Iran
}

\section{*Correspondence to}

Abbas Bahador, Ph.D; Department

of Microbiology, School of

Medicine, Tehran University of

Medical Sciences, Tehran, Iran.

Tel: +98-2188015017

Fax: +98-2188015017

Email: abahador@sina.tums.ac.ir

${ }^{\dagger}$ Equal contribution.

Published online 27 October 2015

\section{Introduction}

Microbial agents are considered as the main causative agent of human dental pulp (intraradicular) and periapical (extraradicular or periradicular) lesions. ${ }^{1}$ Recent culture-independent approaches have suggested that the microbiota in these infections is more complex than previously shown by culture-based methods., ${ }^{2,3}$ Molecular biology analysis of the microbial communities in intraradicular and periradicular infection revealed that a mixed consortium of both gram-positive and gram-negative bacteria occurred in most cases and the composition of the bacterial communities varied from individual to individual. ${ }^{4-7}$ In addition to bacteria, fungi and most recently archaea, viruses have been occasionally found in intraradicular infections. ${ }^{8}$ Among the fungi afflicting human dental pulp, Candida albicans is the most common. ${ }^{9}$ Because viruses are unable to generate energy and fully depend on the viable host cells during replication, they cannot survive in a necrotic root canal. ${ }^{10}$ Human cytomegalovirus and Epstein-Barr virus may be implicated in the pathogenesis of intraradicular infections. ${ }^{11,12}$

Microorganisms colonizing intraradicular and periradicular locations can either be the commensals associated with a healthy oral cavity, or the pathogens associated with oral infections, such as periodontal disease and dental caries. ${ }^{13}$ Intraradicular and periradicular infections are polymicrobial, predominantly anaerobic infection with little microbial specificity. ${ }^{8,14}$ The severity of these infections may be related to the microbial community's composition topped off with loads and virulence, as the latter are other important factors with impact on disease management and prognosis. ${ }^{14}$ Biofilm formation, presence of bacterial modulins, synthesis of enzymes, interbacterial cell-cell coaggregation, nutrient effects, modulation of virulence factors and ability to evade host defenses as virulence factors of intraradicular and periradicular microorganisms, have been reported to contribute to endodontic pathogenesis (Table 1). ${ }^{15-20}$

An understanding of the various virulence mechanisms used by these endodontic pathogens is crucial for the de- 
velopment of novel treatment modalities. ${ }^{21}$

The final objective of endodontic treatment is an effort to obtain conditions to promote the cure and health of the root, as well as prevention or resolution of periapical disease, by the eradication of microorganisms and their sources of nutrient supply from the root canal system. ${ }^{22}$ Accordingly, endodontic treatment including intra-canal procedures such as chemomechanical preparation (instrumentation with copious antimicrobial irrigants) are supplemented or not by a current interappointment intra-canal medication, followed by obturation and ended with perfect restoration. ${ }^{23,24}$ The success rate of this procedure is critically dependent on the management of pulpal space infection, which results in reduction of bacterial numbers. ${ }^{25}$ It has been shown that, conventional endodontic treatment can occasionally fail to promote total eradication of microorganisms from root canals, with consequent selection of the most resistant subpopulation of the microbiota and may lead to treatment failure. ${ }^{26}$ The purpose of this review was to provide background information on the microbiota and virulence determinants of the intraradicular and periradicular infections, as well as to gain a better understanding of endodontic disinfection procedures.

\section{Chemomechanical Debridement}

Mechanical debridement which includes removal of pulpal tissue from the root canal system, making adequate space for irrigation and medication, maintenance of integrity and location of the apical part of the root canal and formation of a suitable form to facilitate root canal filling, is considered a critical step in endodontic treatment. However, studies showed some limitations of this procedure, as a result of deep bacterial penetration to accessory canals, isthmus and dentinal tubules..$^{27,28}$ Also, some studies have shown that mechanical instrumentation alone leaves some parts of the root canal untouched..$^{29}$ To overcome these deficiencies, the application of antimicrobial irrigants and intra-canal medicaments is necessary. Suitable irrigants should have some characteristics such as broad antimicrobial spectrum, ability to avoid smear layer formation, ability to dissolve necrotic pulpal tissue and should be non-toxic to the periradicular tissue. Until now, no irrigant was found with these characteristics. ${ }^{30}$

\section{Sodium Hypochlorite}

Sodium hypochlorite is one of the most widely used antimicrobial irrigants in endodontic treatment. It has the ability to cause necrosis, hemolysis and skin ulceration due to its cytotoxicity. It shows some bactericidal effects through oxidative action of the undissociated hypochlorous acid on the sulphydryl groups of bacterial enzymes. The inhibition of enzyme interferes with metabolic function of bacteria. ${ }^{31-33}$

\section{Ethylenediaminetetraacetic Acid}

Ethylenediaminetetraacetic acid (EDTA) is a water solu- ble solid. It produces decalcified dentin by reacting with calcium ions. It shows little antibacterial activity. Its antibacterial effect is related to chelation of cations from the outer membrane of bacteria. EDTA also has the ability to remove the inorganic portion of the smear layer. It shows some cytotoxic effects. ${ }^{34,35}$

\section{Citric Acid}

Citric acid also has limited antibacterial effects compared to its capacity to remove inorganic parts of smear layer. ${ }^{36}$

\section{MTAD}

MTAD, a common intra-canal irrigant, is a mixture of 3\% doxycycline (a tetracycline), $4.25 \%$ citric acid, and $0.5 \%$ polysorbate 80 detergents that is used for the endodontic therapy. Its antibacterial effect is attributed largely to doxycycline that inhibits bacterial protein synthesis, by preventing the association of aminoacyl-tRNA with the bacterial ribosome. ${ }^{37}$ Resistance to doxycycline is not uncommon among the bacteria isolated from root canals. ${ }^{38}$ Different mechanisms of acquired resistance to doxycycline have been described with ribosomal protection, efflux of the antibiotic from the bacterial cell and enzymatic inactivation of the antibiotic as major modes of action. ${ }^{39}$

\section{Nisin}

Nisin, a polycyclic antibacterial peptide was used as a substitute for or in combination with doxycycline, in order to improve the bactericidal activity of MTAD. ${ }^{40}$ Nisin, an antimicrobial peptide produced by Lactococcus lactis, has been extensively used as a preservative in dairy products. This peptide is composed of 34 amino acid residues, including such unusual amino acids as lanthionine (Lan), methyllanthionine (MeLan), didehydroalanine (Dha) and didehydroaminobutyric acid (Dhb)..$^{38}$ Nisin inhibits the proliferation of most gram-positive bacteria and is heat-stable, odorless, colorless, tasteless, active at low $\mathrm{pH}$ and soluble in water and can be effective at levels nearing the parts-per-billion range.

\section{MTADN}

MTADN (nisin combined with MTAD) had the best antibacterial activity in evaluating the effects of MTAD, MTAN (nisin in place of doxycycline in MTAD), and MTADN on Enterococcus faecalis during the exponential growth phase and stress states. Nisin improved the post-antibacterial effect of MTAD and has considerable potential for use as a modification of MTAD and it has potential as an intra-canalirrigant. ${ }^{40}$

\section{NanoAg-MTA}

To prevent endodontic-periodontal infection after repairing root perforations, an obturation material with robust antimicrobial activity such as silver nanoparticles (NanoAg) -MTA is highly desirable. It has been shown that in the NanoAg-MTA, Nano Ag effectively enhanced 
High Technology Techniques in Control and Elimination of Endodontic Micorbiota

Table 1. Main Distinctive Features of the Mcrobiota Associated With Different Types of Endodontic Infections

\begin{tabular}{|c|c|c|c|c|}
\hline Type of infections & \multicolumn{2}{|c|}{$\begin{array}{l}\text { Primary infection } \\
\text { Chronic Apical Periodontitis/Acute Apical Abscess }\end{array}$} & \multicolumn{2}{|c|}{$\begin{array}{l}\text { Persistent/Secondary Infections } \\
\text { Filling Stage/Treated Teeth }\end{array}$} \\
\hline Community & \multicolumn{2}{|l|}{ Mixed } & \multicolumn{2}{|l|}{ Mixed, sometimes single } \\
\hline No. taxa/case & \multicolumn{2}{|l|}{$10-20$} & \multicolumn{2}{|l|}{$1-5$} \\
\hline Uncultivated bacteria & \multicolumn{2}{|l|}{$40 \%-55 \%$} & \multicolumn{2}{|l|}{$42 \%-55 \%$} \\
\hline Most prevalent groups & \multicolumn{2}{|c|}{ Gram-negative/gram-positive anaerobes } & \multicolumn{2}{|c|}{ Gram-positive/gram-negative facultative/anaerobes } \\
\hline & $\begin{array}{l}\text { Most prevalent species } \\
\text { (\% prevalence) }\end{array}$ & Virulence factors & $\begin{array}{l}\text { Most prevalent } \\
\text { species (\% prevalence) }\end{array}$ & Virulence factors \\
\hline & $\begin{array}{l}\text { Filifactor alocis } \\
\mathrm{G}+/ \mathrm{An} \\
(48)\end{array}$ & $\begin{array}{l}\text { Metal-dependent } \\
\text { proteases } \\
\text { Trypsin-like proteases } \\
\text { Sialoglycoproteases }\end{array}$ & $\begin{array}{l}\text { Enterococcus faecalis } \\
\mathrm{G}+/ \mathrm{F} \\
(64-78)\end{array}$ & $\begin{array}{l}\text { Hemolysin/cytolysin } \\
\text { Gelatinase (GelE) } \\
\text { Hyaluronidase } \\
\text { Enterococcal surface protein (Esp) } \\
\text { E. faecalis regulator (Fsr) } \\
\text { Aggregation substance (AS) } \\
\text { Microbial surface component } \\
\text { recognizing adhesive matrix } \\
\text { molecule adhesin of collagen } \\
\text { from Enterococci (MSCRAMM } \\
\text { Ace) } \\
\text { Serine protease (SprE) } \\
\text { Sex pheromones } \\
\text { Second collegen adhesin of E. } \\
\text { faecalis (Scm) } \\
\text { Lipoteichoic acid } \\
\text { Capsule } \\
\text { Cell wall polysaccharide } \\
\text { Extracellular superoxide } \\
\text { Heat-shock proteins }\end{array}$ \\
\hline & $\begin{array}{l}\text { Pseudoramibacter } \\
\text { alactolyticus } \\
\mathrm{G}+/ \mathrm{An} \\
\text { (52) }\end{array}$ & Chemotaxis & $\begin{array}{l}\text { Streptococcus } \\
\text { anginosus } \\
\mathrm{G}+/ \mathrm{F} \\
(7-53)\end{array}$ & $\begin{array}{l}\text { Polysaccharide capsule } \\
\text { Pyrogenic exotoxins } \\
\text { Hyaluronidase } \\
\text { Peptidoglycan } \\
\text { Lipoteichoic acid } \\
\text { Metabolites }\end{array}$ \\
\hline & $\begin{array}{l}\text { Parvimonas spp. } \\
\mathrm{G}+\text { / An } \\
\text { P. micra (formerly } \\
\text { Peptostreptococcus } \\
\text { micros) (22-78) }\end{array}$ & $\begin{array}{l}\text { Peptidases } \\
\text { Hyaluronidase } \\
\text { Capsule } \\
\mathrm{H}_{2} \mathrm{~S} \\
\text { Capsule } \\
\text { Surface proteins } \\
\text { Collagenase }\end{array}$ & $\begin{array}{l}\text { Streptococcus mitis } \\
\mathrm{G}+/ \mathrm{F}(7-46) \\
\\
\text { Streptococcus } \\
\text { sanguinis } \\
\mathrm{G}+/ \mathrm{F}(7-28)\end{array}$ & $\begin{array}{l}\text { Choline-binding proteins (CBPs) } \\
\text { Hydrogen peroxide }\end{array}$ \\
\hline & & & $\begin{array}{l}\text { Filifactor alocis } \\
\mathrm{G}+/ \text { An (46-57) }\end{array}$ & $\begin{array}{l}\text { Metal-dependent proteases } \\
\text { Trypsin-like proteases } \\
\text { Sialoglycoproteases }\end{array}$ \\
\hline & $\begin{array}{l}\text { Treponema spp. } \\
\mathrm{G}-/ \mathrm{F} \\
\text { T. maltophilum (89) } \\
\text { T. socranskii (75) } \\
\text { T. denticola (36-79) } \\
\text { T. parvum (22-39) }\end{array}$ & $\begin{array}{l}\text { Biofilm } \\
\text { Motility } \\
\text { Cystalysin } \\
\text { Outer membrane } \\
\text { dentilisin protease } \\
\text { Lipoprotein complex } \\
\text { Toxin antitoxin systems } \\
\text { Transposases } \\
\text { Trypsin-like protease } \\
\text { Periplasmic flagella } \\
\text { Major surface protein } \\
\text { (Msp) } \\
\text { Chymotrypsin-like } \\
\text { protease complex } \\
\text { Extracellular or } \\
\text { membrane-associated } \\
\text { proteolytic and } \\
\text { hydrolytic enzymes } \\
\text { Lipooligosaccharide } \\
\text { Lipoprotein } \\
\text { Phospholipases } \\
\text { Metabolites (acetic and } \\
\text { lactic acids, } \mathrm{H}_{2} \mathrm{~S} \text { ) } \\
\text { Heat-shock proteins }\end{array}$ & $\begin{array}{l}\text { Actinomyces spp. } \\
\mathrm{G}+\text { / An } \\
\text { A. israelii (1-20) } \\
\text { A. naeslundii (7-20) } \\
\text { A. viscosus (7) }\end{array}$ & Fimbriae \\
\hline
\end{tabular}




\begin{tabular}{|c|c|c|c|}
\hline $\begin{array}{l}\text { Tannerela forsythia } \\
\text { G -/ An } \\
\text { (30-64) }\end{array}$ & $\begin{array}{l}\text { Trypsin-like protease } \\
\text { SiaHI sialidases } \\
\text { NanH sialidases } \\
\text { S-layer } \\
\text { Lipopolysaccharide } \\
\text { Acid phosphatase } \\
\text { Metabolites (acetic, } \\
\text { propionic, butyric, } \\
\text { isovaleric and } \\
\text { phenylacetic acids) } \\
\text { Apoptosis-inducing } \\
\text { factor } \\
\text { Heat-shock proteins }\end{array}$ & $\begin{array}{l}\text { Parvimonas micra } \\
\mathrm{G}+/ \mathrm{An} \\
(5-60)\end{array}$ & $\begin{array}{l}\text { Peptidases } \\
\text { Hyaluronidase } \\
\text { Capsule } \\
\mathrm{H}_{2} \mathrm{~S}\end{array}$ \\
\hline $\begin{array}{l}\text { Porphyromonas spp. } \\
\text { G -/ An } \\
\text { P. endodontalis (15-68) } \\
\text { P. gingivalis (30) }\end{array}$ & $\begin{array}{l}\text { Fimbriae } \\
\text { Trypsin-like proteinase } \\
\text { Cysteine protease } \\
\text { Biofilm } \\
\text { Lipopolysaccharide } \\
\text { Capsule } \\
\text { Outer membrane } \\
\text { proteins } \\
\text { Outer membrane } \\
\text { vesicles } \\
\text { Acid phosphatase } \\
\text { Metabolites (butyric } \\
\text { and propionic acids, } \\
\text { indole, } \mathrm{H}_{2} \mathrm{~S} \text { ) } \\
\text { Lipoproteins } \\
\text { Phospholipase } \\
\text { DNase } \\
\text { Hyaluronidase } \\
\text { Fibrinolysin } \\
\text { Chondroitin sulfatase } \\
\text { Hemolysins } \\
\text { Heat-shock proteins }\end{array}$ & $\begin{array}{l}\text { Lactobacillus spp. } \\
\text { G +/ F } \\
(7-35)\end{array}$ & See primary infection \\
\hline $\begin{array}{l}\text { Fusobacterium spp. } \\
\text { G-/ An } \\
\text { F. nucleatum (19-86) } \\
\text { F. necrophorum (23) } \\
\text { F. periodonticum (19) }\end{array}$ & $\begin{array}{l}\text { Heat shock proteins } \\
\text { Lipopolysaccharide } \\
\text { Outer membrane } \\
\text { proteins } \\
\text { Capsule } \\
\text { Metabolites (butyric } \\
\text { and propionic acids, } \\
\text { ammonia, indole) } \\
\text { Serine protease } \\
\text { Synergistic interaction } \\
\text { with facultative } \\
\text { organisms or other } \\
\text { anaerobes }\end{array}$ & $\begin{array}{l}\text { Olsenella spp. } \\
\mathrm{G}+\text { / An } \\
\text { O. profusa (7-100) } \\
\text { O. uli (27-67) }\end{array}$ & See primary infection \\
\hline $\begin{array}{l}\text { Prevotella spp. } \\
\mathrm{G} \text {-/ An } \\
\text { P. denticola (77) } \\
\text { P. oralis (40) } \\
\text { P. baroniae (35) } \\
\text { P. buccae (29) } \\
\text { P. melaninogenica (26- } \\
\text { 29) } \\
\text { P. intermedia/nigrescens } \\
\text { (22-69) } \\
\text { P. tannera (18-35) } \\
\text { P. ruminicola (29) } \\
\text { P. oris (39-67) }\end{array}$ & $\begin{array}{l}\text { Fimbria } \\
\text { Lipopolysaccharide } \\
\text { Metabolites (indole, } \\
\mathrm{H}_{2} \mathrm{~S} \text {,ammonia, acetic } \\
\text { and succinic acids) } \\
\text { Proteinases } \\
\text { Hemolysins } \\
\text { Acid phosphatase } \\
\text { Phospholipase } \\
\text { Heat-shock proteins }\end{array}$ & $\begin{array}{l}\text { Pseudoramibacter } \\
\text { alactolyticus } \\
\mathrm{G}+/ \mathrm{An} \\
(50)\end{array}$ & Unknown \\
\hline $\begin{array}{l}\text { Campylobacter spp. } \\
\text { G -/ M } \\
\text { C. rectus }(80) \\
\text { C. gracilis }(30)\end{array}$ & $\begin{array}{l}\text { Extracellular cytotoxin } \\
\text { Lipopolysaccharide } \\
\text { S-layer } \\
\text { Arylsulfatase } \\
\mathrm{H}_{2} \mathrm{~S} \\
\text { Heat-shock proteins }\end{array}$ & $\begin{array}{l}\text { Propionibacterium spp } \\
\mathrm{G}+/ \mathrm{F} \\
\quad \text { P. propionicum (52) } \\
\text { P. acnes (27-52) } \\
\text { P. acidifaciens (14) }\end{array}$ & $\begin{array}{l}\text { Biofilm formation } \\
\text { Lipase }\end{array}$ \\
\hline $\begin{array}{l}\text { Dialister spp. } \\
\text { G -/ An } \\
\text { D. pneumosintes (48-78) } \\
\text { D. invisus (53) }\end{array}$ & Unknown & $\begin{array}{l}\text { Pseudomonas } \\
\text { aeruginosa } \\
\mathrm{G}-/ \mathrm{A} \\
\text { (48) }\end{array}$ & $\begin{array}{l}\text { Cell-cell signalling } \\
\text { Protease profiles } \\
\text { Biofilm }\end{array}$ \\
\hline
\end{tabular}




\begin{tabular}{|c|c|c|c|}
\hline $\begin{array}{l}\text { Streptococcus spp. } \\
\mathrm{G}+/ \mathrm{F} \\
\text { S. milleri (31-50) } \\
\text { S. constellatus (20-35) } \\
\text { S. intermedius (35) }\end{array}$ & $\begin{array}{l}\text { Hyaluronidase } \\
\text { Deoxyribonuclease } \\
\text { Hydrolytic enzymes }\end{array}$ & $\begin{array}{l}\text { Dialister spp. } \\
\text { G-/ An } \\
\text { D. pneumosintes } \\
\text { (46) } \\
\text { D. invisus (30) }\end{array}$ & Unknown \\
\hline $\begin{array}{l}\text { Bacteroides spp. } \\
\text { G -/ An } \\
\text { Bacteroidetes clone } X 083 \\
(36-60)\end{array}$ & $\begin{array}{l}\text { Lipopolysaccharide } \\
\text { Capsular polysaccharide }\end{array}$ & $\begin{array}{l}\text { Solobacterium moorei } \\
\text { G + An } \\
(33-78)\end{array}$ & Gelatin hydrolysis \\
\hline $\begin{array}{l}\text { Peptostreptococcus spp. } \\
\mathrm{G}+/ \text { An } \\
\text { P. anaerobius (53-64) }\end{array}$ & $\begin{array}{l}\text { Capsular polysaccharide } \\
\text { Synergistic interaction } \\
\text { with Facultative } \\
\text { organisms or other } \\
\text { anaerobes }\end{array}$ & $\begin{array}{l}\text { Pyramidobacter } \\
\text { piscolens } \\
\text { G -/ An } \\
(60)\end{array}$ & Unknown \\
\hline $\begin{array}{l}\text { Peptococcus spp. } \\
\text { G +/ An } \\
\text { (64) }\end{array}$ & $\begin{array}{l}\text { Extracellular enzymes } \\
\text { (DNase, RNase, } \\
\text { coagulase, and } \\
\text { hemolysins) }\end{array}$ & $\begin{array}{l}\text { Bacteroidetes clone } \\
\text { X083 } \\
\text { (53) }\end{array}$ & See primary infection \\
\hline $\begin{array}{l}\text { Lactobacillus spp. } \\
\mathrm{G}+/ \text { An } \\
\text { (65) }\end{array}$ & $\begin{array}{l}\text { Adhesion proteins } \\
\text { Survive in acidic } \\
\text { conditions }\end{array}$ & $\begin{array}{l}\text { Fusobacterium } \\
\text { nucleatum } \\
(24-40)\end{array}$ & See primary infection \\
\hline $\begin{array}{l}\text { Eggerthella lenta } \\
\mathrm{G}+/ \mathrm{An} \\
\text { (47) }\end{array}$ & $\begin{array}{l}\text { Cardiac glycoside } \\
\text { reductase (digoxin } \\
\text { inactivation enzyme) }\end{array}$ & $\begin{array}{l}\text { Peptostreptococcus } \\
\text { stomatis (43) }\end{array}$ & See primary infection \\
\hline $\begin{array}{l}\text { Anaerococcus prevotii } \\
\mathrm{G}+/ \mathrm{An}(43)\end{array}$ & Unknown & T. forsythia (12) & See primary infection \\
\hline $\begin{array}{l}\text { Gemella morbillorum } \\
\text { G +/ F } \\
\text { (30) }\end{array}$ & $\begin{array}{l}\text { Same pathogenic } \\
\text { mechanisms found in } \\
\text { viridans streptococci }\end{array}$ & F. nucleatum (33) & See primary infection \\
\hline $\begin{array}{l}\text { Olsenella uli } \\
\mathrm{G}+/ \mathrm{An} \\
\text { (45) }\end{array}$ & Biofilm formation & $\begin{array}{l}\text { Candida albicans } \\
\text { (yeast) } \\
\text { F } \\
\text { (9) }\end{array}$ & $\begin{array}{l}\text { Mannose-containing proteins } \\
\text { Mannan } \\
\text { Phospholipase } \\
\text { Proteinases } \\
\text { Hyaluronidase } \\
\text { Acid phosphatase } \\
\text { Chondroitin sulfatase } \\
\text { Phospholipase } \\
\text { Heat-shock proteins }\end{array}$ \\
\hline
\end{tabular}

\begin{tabular}{|c|c|}
\hline $\begin{array}{l}\text { Eikenella corrodens } \\
\text { G -/ F (38) }\end{array}$ & Biofilm formation \\
\hline $\begin{array}{l}\text { Lachnospiracea spp. } \\
\text { G +/ An } \\
\text { L. clone 55A-34 (57) } \\
\text { L. clone MCE7_60 (43) }\end{array}$ & Unknown \\
\hline $\begin{array}{l}\text { Eubacterium spp. } \\
\mathrm{G}+\text { / An } \\
\text { E. clone BP1-89 (43) } \\
\text { E. brachy (56) }\end{array}$ & Unknown \\
\hline $\begin{array}{l}\text { Phocaeicola spp. } \\
\text { G -/ An } \\
(100)\end{array}$ & Unknown \\
\hline
\end{tabular}

Abbreviations: G -, gram negative; G +, gram positive; F, facultative anaerobic; An, anaerobic; A, aerobic; M, microaerophilic.

the antimicrobial activity of MTA, so the NanoAg-MTA demonstrated a potent antimicrobial activity against four important anaerobic periodontal/endodontic pathogens namely Aggregatibacter actinomycetemcomitans, Fusobacterium nucleatum, Porphyromonas gingivalis, and Prevotella intermedia in vivo. ${ }^{41}$

\section{Chlorhexidine}

Chlorhexidine is a hydrophobic, positively charged and lipophilic molecule which interacts with lipopolysaccharides on the cell membrane of bacteria. It is used in $2 \%$ gel or liquid concentration of $0.2 \%{ }^{42}$ It has bactericidal effects against gram-negative and gram-positive microorganisms; 
no study has reported the toxicity, teratogenic and cancerogenic effects of chlorhexidine (CHX) on organism. The inability of this irrigant to dissolve necrotic tissue remnants is considered as a disadvantage. Also, 2-min rinse of $2 \% \mathrm{CHX}$ liquid can remove bacteria from superficial layers of dentinal tubules only up to $100 \mu \mathrm{m} .{ }^{43,44}$

\section{Passive Ultrasonic Irrigation (PUI)}

Ultrasonic irrigation promoted best results in some studies. It shows some advantages like efficiency, time-wise and economical. It improves the effects of intra-canal solution by acoustic streaming. The solution can spread to all parts of the canal even in non-instrumented parts where intact biofilm can be found. ${ }^{45}$

\section{Lasers}

Recently, laser was introduced to endodontics to improve the results acquired by traditional techniques. Different wavelengths have been shown to be effective in reducing bacteria in the root canal system. ${ }^{46}$ Among the different wavelengths used in dentistry, neodymium-doped yttrium aluminium garnet (Nd:YAG) laser is considered as the best wavelength for intra-canal disinfection due to its penetration depth close to bacterial penetration in dentinal tubules. ${ }^{47}$ This penetration depth can be explained by the ability of enamel prisms and dentinal tubules acting as optical fiber, to propagate the laser to the dentinal periphery of the root. ${ }^{48}$

Diode laser with wavelength range of 800 to $1064 \mathrm{~nm}$ is another option for root canal disinfection acting through thermal effect. Diode lasers have gained importance in dentistry based on their affordability and small size. ${ }^{49}$ Different studies reported that the application of diode laser for bacterial decontamination produced different success rates dependent on the amount of energy applied and dentin thickness. ${ }^{50,51}$ After chemomechanical preparation, irradiation is performed as a final step for decontaminating the root canal system before obturation. An optical fiber with $200 \mu \mathrm{m}$ diameter and $1 \mathrm{~mm}$ shorter that the working length is placed inside the canal, starting irradiation with circular movement in the apical-coronal direction. ${ }^{52}$ Some studies suggested applying this technique in canals filled with irrigants such as EDTA, citric acid or $\mathrm{NaOCl}$ reduces the thermal side effects. ${ }^{53}$ It should be considered that irradiation of the Nd:YAG and diode laser can create fusion and superficial re-solidification in the dentine with a clear glazed surface. ${ }^{54}$

We should always keep in mind that it is better to move the fiber inside the canal and not to stay or touch the root canal wall for a long time to avoid producing craters with microcracks. Although there is no statistic correlation between microcracks and a possibility of increase of root fractures in the future, it is better not to create them. ${ }^{55}$ The Erbium family laser with two different wavelength including erbium-doped yttrium aluminium garnet (Er:YAG) and erbium, chromium doped yttrium scandium gallium garnet (Er-Cr:YSGG) laser was approved for dental proce- dure in 1997 by FDA. ${ }^{56}$ Laser activated irrigation (LAI) is defined as activation of irrigation by lasers. It seems that the erbium family can be effective in this subject regarding their affinity for water. ${ }^{57}$ Cavitation effect caused by this wavelength with formation and implosion of vapor bubble which results in very fast movement of intra-canal solution. ${ }^{58}$ These techniques (such as LAI and PIPS) are able to diminish the undesirable thermal effects on the dentinal walls, by application of lower energies accompanied by chemical irrigants. ${ }^{59}$ It has been proved that EDTA can be the best solution for the LAI, by enhancing the capability of smear layer removal. ${ }^{60}$

Another technique called the photon induced photoacoustic streaming (PIPS) is based on strong agitation of intra-canal irrigants. The advantages of this technique can be summarized to the reduction of thermal effect and stronger cleaning and bactericidal action, owing to streaming of irrigants by the photonic energy of the laser. ${ }^{61}$ The difference between LAI and PIPS can be attributed to the placement of the tip in the coronal part of orifices in the PIPS technique compared to $5 \mathrm{~mm}$ above the apex in LAI which eliminates the tip introduction into the root canal. ${ }^{62}$ The tip used for this technique has a special design (tapered) with $600 \mu \mathrm{m}$ in diameter and $9 \mathrm{~mm}$ length. It has greater lateral emission rather than in the frontal part. ${ }^{60}$ Studies are currently ongoing, for further confirmation of LAI and PIPS techniques.

\section{Photodynamic Therapy}

Photodynamic therapy (PDT) uses light of a specific wavelength to activate a nontoxic photoactive dye (photosensitizer) in the presence of oxygen to produce cytotoxic products that give rise to the preferred therapeutic effects. ${ }^{63}$ Various terms are used for PDT such as photoactivated chemotherapy (PACT), photodynamic disinfection (PDD), light-activated disinfection (LAD), and photoactivated disinfection (PAD) in different studies and literature. ${ }^{64}$ The successful outcome of PDT depends on the optimal interaction among three elements - light, PS and oxygen. ${ }^{65}$

\section{Photosensitizers}

A photosensitizer (PS) is a chemical compound, which when exposed to light at specific wavelength, reacts with oxygen to produce highly reactive oxygen species (ROS) which results in cell death.

The ideal characteristics of a PS include:

- Chemical purity non-toxic

- Ability to target the tissue, cost-effective, easily available

- Short interval between administration of the drug and peak accumulation in the tissue

- Short half-life

- Rapid elimination from normal tissue

- Activation at wavelength at which penetration into the target tissue is very good

- Ability to produce a large amount of 
cytotoxic products. ${ }^{66}$

\section{Methylene Blue}

3,7-bis(dimethylamino)-phenothiazin-5-ium chloride was first synthesized by a German chemist called Henrich Caro in 1876. Then, in 1885 Paul Ehrlich realized its advantages for selective coloring in histology. ${ }^{67,68}$ Methylene blue (MB) is a hydrophilic PS with low molecular weight and positive charge. This PS can be used for both gram-positive and gram-negative oral bacteria. The solution penetrates through the porin channels in the outer membrane of gram-negative bacteria and mostly interacts with the anionic macromolecule lipopolysaccharide generating MB dimmers which take part in the photosensitization process. Its peak absorption is at $660 \mathrm{~nm} .{ }^{69}$

\section{Toluidine Blue $\mathbf{O}$}

Toluidine blue $\mathrm{O}(\mathrm{TBO})$ is also a cationic blue coloring agent (3-amino-7-[dimethylamino]-2-methylphenothiazine) used for histological and intravital staining. It is also used for differential diagnosis between benign and malign precancerous leukoplakia. It has a peak abruption at $635 \mathrm{~nm} .{ }^{70} \mathrm{TBO}$ has the ability to have an effect on both gram-positive and gram-negative bacteria due to its physical and chemical properties and hydrophilic characteristics making it pass the bacterial membrane, and it showed attraction to the mitochondria which has negative charge. $^{71}$

The LPS of the outer cell envelope is the site which TBO binds to in gram-negative bacteria but the teichuronic acid residues of the outer wall is the site of binding in gram-positive bacteria. ${ }^{72}$

\section{Indocyanine Green}

Indocyanine green (ICG), green coloring agent 1,7-Bis(1,1-dimethyl-3-[4-sulfobutyl]-1H-benz[e]indol2-yl)heptamethinium-betain-Na, has recently been used as PS. It was proposed that the mechanism of this PS is somehow different from the other PS. The effect of ICG is mainly photothermal therapy (PTT) rather than photochemical. ${ }^{73}$ It is an anionic PS. Although its absorption critically depends on the dissolving medium, bonds to plasma proteins and its concentration, its peak absorption is at $810 \mathrm{~nm} .{ }^{74}$ The two forms of ICG now in the market are one free from iodide (EmunDo, ARC) while the other contains normal quantities of iodide (perio green ${ }^{\circledR}$, elexxion). There is no evidence regarding allergic or anaphylactic reactions following iodide application in dentistry.

\section{Curcumin}

Curcumin is isolated from Curcuma longa L. which is mainly used as a spice. It has some therapeutic effects on liver diseases, wounds, and inflamed joints, as well as for blood purification and microbial effects. ${ }^{75}$ Curcumin has shown no toxic effects on a number of cell cultures and animal studies. It has a broad absorption peak in the 300$500 \mathrm{~nm}$ range (maximum $430 \mathrm{~nm}$ ) and produces strong phototoxic effects. Therefore, curcumin has the capability to be used as a PS. ${ }^{76,77}$ This PS shows some restriction for being dissolved in water and requires oil or other synthetic material to make possible its solubility in water.

On the other hand, this PS has some advantages like easy handling, low cost and efficacy. ${ }^{78}$ It is important to know that gram-negative bacteria are more susceptible to common PS along with the action of singlet oxygen compared to gram-positive bacteria. This difference is explained by the fact that can be adduced to the structure of gram-negative bacteria consists of lipid bilayers rolling as a physical barrier between the cell and its environment. On the other hand, the LPS in gram-negative bacteria limits the toxic effect of singlet oxygen preventing cell death. ${ }^{79}$

\section{Light}

In photodynamic therapy, the light source which coincides with maximum absorption of the PS applied is required. The light source for PAD can be divided into three main categories namely: (1) broad spectrum lamps, (2) Light emitting diode lamps (LED) and 3) lasers. ${ }^{80}$ Among the different sources, lasers show some advantages like monochromacy which allows the laser to best interact with PS due to matching precisely with its peak absorption, which reduces unnecessary tissue heating by bandwidths not effective in PDT reaction. ${ }^{81}$ In dentistry, most of the PS are activated by the red light wave lengths between 630-700 $\mathrm{nm}$. Presently, with the introduction of new PS such as ICG, infrared laser like $810 \mathrm{~nm}$ is also used..$^{82}$

In PDT endodontic disinfection, blue light (400-500 nm) can be a suitable option for some reasons. First, it is available in nearly all dental offices for curing of dental resin composites. Second, it creates free radicals more efficiently compared to red light. Third, blue light sources produce a much larger spectral emission (400-500 nm) than lasers which are capable of activating PS leading to the production of free radicals. Compared to lasers as light source, LEDs are more cost effective and compact. ${ }^{83}$

\section{Mechanism of Photodynamic Therapy}

After the activation of PS with appropriate wavelength, electrons are transferred from a low to a higher level of energy which is called the triplet state. Then, the energy is transferred to a biomolecule or to oxygen which leads to the production of cytotoxic species. These products damage the cellular plasma membrane or the cell DNA. Both consequences lead to cell death. ${ }^{84}$

The transfer of electrons in activated PS can be done in two pathways including transfer to the neighboring molecule (type- 1 reaction) or to oxygen (type- 2 reaction) to produce reactive oxygen species (ROS), typically singlet oxygen. Although, the two pathways can have a role on bacterial killing, type 2 by producing highly reactive singlet oxygen is detected as the main pathway in killing bacteria..$^{85,86}$

This mechanism is different from that of antibiotics; hence the resistance of bacterial strain is not likely, due to acting 
on multiple targets inside the bacteria. ${ }^{87}$ The absence of thermal effect in PDT procedure is considered as one of the main advantages in endodontic disinfection, with a lack of thermal side effects in periradicular tissues. The main mechanism of lethal action is based on photochemical reaction. ${ }^{88}$ Another advantage of PDT is that it contributes to the enhancement of cross-linking of collagen fibrils in the dentin matrix, thereby improving dentin stability. Furthermore, ROS generated by PDT increase the number of intermolecular cross-links between adjacent collagen fibrils and result to higher resistance of collagen to enzymatic degradation at contaminated places. Collagen is the main structural protein of the dentin matrix, increase in collagen cross-linking increases the mechanical properties of dentin in infectious condition inside the canal. ${ }^{89}$

Two mechanisms have a major role in lethal damage administered by PDT, (i) DNA damage, (ii) damage to cytoplasmic membrane and cellular contents or inactivation of membrane transport systems and enzymes. ${ }^{90}$ It seems that the DNA damage is a more important mechanism for PDT of bacteria. In both gram-positive and gram-negative species, breakdowns of single-stranded and double-stranded DNA occur, as well as fading of the plasmid super-coiled fraction. $^{91}$

One of the main concerns during photodynamic therapy is the photosensitivity of bacteria which seems related to the charge of the PS used. The neutral or anionic PS binds effectively to gram-positive bacteria. They also bind to some degree to the outer membrane of gram-negative bacteria. ${ }^{92}$ The porous layer of peptidoglycan and lipoteichoic acid outside the cytoplasmic membrane of gram-positive species allow the PS to penetrate into the sensitive sites. On the other hand, the outer membrane of gram-negative bacteria acts as a physical barrier between cells and its environment. The binding of negatively charged PS to gram-negative bacteria may be improved by linking the PS to a cationic molecule ${ }^{93,94}$.

The success rate of photodynamic therapies depend on the type, dose, incubation time, and localization of the PS, the availability of oxygen, the wavelength of light $(\mathrm{nm})$, the light power density and the light energy fluency. ${ }^{95}$ Limitations of this treatment which should be taken into account are the low-oxygenated environment and the diffusion ability of the PS and light to be used..$^{96}$

\section{Discussion}

The chemomechanical technique cannot completely eliminate the bacteria in root canal treatment. Due to the limitation in penetration depth of conventional irrigants such as $\mathrm{NaOCl}$, bacteria remaining in accessory canals cannot be removed..$^{97}$ In order to improve the success rate of the root canal therapy (RCT) procedure, other technologies were introduced. Laser as a new technology has the potential to eradicate the bacteria from root canals through photothermal reactions. In this regard, different wavelengths were used. Although the application of laser can enhance the results of treatment, the thermal effects on the dentine are considered to be a main concern..$^{98}$

Antimicrobial photodynamic therapy (aPDT) is a recently known technique for disinfection in dentistry; its lethal action is based on photo chemical reaction with no thermal effect compared to laser treatment, which protects the adjacent tissues. ${ }^{99}$ On the other hand, it should be kept in mind that the application of some PS like MB can stain the teeth if the appropriate concentration is not used. However, there are evidences suggesting that the application of $\mathrm{NaOCl} 2.5 \%$ is effective in the prevention of tooth discoloration after applying PS. It was suggested that MB in concentrations below $100 \mu \mathrm{g} / \mathrm{ml}$, reduces the chance of tooth discoloration. ${ }^{100}$

Another advantage of aPDT is its safety. Studies showed that the cytotoxicity produced by aPDT is relatively less than $\mathrm{NaOCl}$ when used for RCT. ${ }^{101}$ One of the criteria that influence the success rate of aPDT is the species of bacteria and their growth. Silva et al in assessing aPDT on five different strains of $E$. faecalis, concluded that the efficacy of aPDT on E. faecalis biofilms was strain dependent due to variability in the phenotype and genotype of clinical strains. ${ }^{102}$

The complexity of the root canal, the oxygen content and the diffusion ability of PS, also have an effect on the outcome. There is a study which reported the efficacy of $\mathrm{PDT}$ on anterior and posterior teeth with the same success rate. ${ }^{103}$ If the oxygen content in the site of treatment is low, the possibility of cytotoxic oxygen is also reduced, thereby reducing the efficacy of treatment. ${ }^{104}$ There can be some restriction on the diffusion of PS inside the canal, such as some irregularities or bacterial biofilm on untouched walls. In order to improve the penetration of PS, some chelating solutions like EDTA or citric acid can be used prior to PDT or the PS can be prepared by these solutions. Also, ultrasonic waves can be used to place the PS deeper. ${ }^{105}$ Among different PS presented in this article, it seems that ICG can be beneficial due to its peak absorption at $808 \mathrm{~nm}$, which coincides with the commercial diode devices with extensive application such as soft tissue surgery, bleaching, etc. Also, this wavelength has more penetration depth compared to red lasers used for TBO and MB. It is suggested to use PS after application of chelating solution or EDTA or citric acid-based PS prepared by this solution then ultrasonic waves are used to place the PS deeper, then an appropriate wavelength is used to activate the PS.

\section{Conclusion}

Each technique for endodontic disinfection has some advantages and disadvantages. Among these different techniques and due to the development of laser technology in dentistry, the application of PDT has gained special attention. It would be helpful to recognize the best combination of PS and light wavelength through in vitro studies and conduct randomized controlled trials, to investigate the efficacy of PDT on root canal disinfection. 


\section{References}

1. Peciuliene V, Maneliene R, Balcikonyte E, Drukteinis S, Rutkunas V. Microorganisms in root canal infections: a review. Stomatologija. 2008;10(1):4-9.

2. Rôças IN, Siqueira JF. Characterization of microbiota of root canal-treated teeth with posttreatment disease. J Clin Microbiol. 2012;50(5):1721-1724. doi:10.1128/ jcm.00531-12

3. de Paula VA, PinheiroRdos S, de Lima Pedro R, dos Santos KR, Salignac Primo LG, Maia LC. Microorganisms involved in endodontic infection of permanent teeth: a systematic review. Afr J Microbiol Res. 2013;7(18):1819-1826.

4. Tzanetakis GN, Azcarate-Peril MA, Zachaki S, et al. Comparison of bacterial community composition of primary and persistent endodontic infections using pyrosequencing. J Endod. 2015. pii: S00992399(15)00242-3. doi:10.1016/j.joen.2015.03.010

5. Hong BY, Lee TK, Lim SM, et al. Microbial analysis in primary and persistent endodontic infections by using pyrosequencing. J Endod. 2013;39(9):11361140.

6. Shang JJ, Yang QB, Zhao HY, Cai S, Zhou Y, Sun Z. Preliminary molecular analysis of bacterial composition in periapical lesions with primary endodontic infections of deciduous teeth. Chin Med $J$ (Engl). 2013;126(16):3112-3117.

7. Siqueira JF Jr, Rôças IN. Diversity of endodontic microbiota revisited. J Dent Res. 2009;88(11):969981. doi:10.1177/0022034509346549

8. Narayanan LL,Vaishnavi C. Endodontic microbiology. J Conserv Dent. 2010;13(4):233-239. doi:10.4103/0972-0707.73386

9. Kumar J, Sharma R, Sharma M, Prabhavathi V, Paul J, Chowdary CD. Presence of Candida albicans in root canals of teeth with apical periodontitis and evaluation of their possible role in failure of endodontic treatment. J Int Oral Health. 2015;7(2):42-45.

10. Latoo S, Shah AA, Ahmad I, Qadir S, Bhagat RK, Lone KA. Endodontic microbiology: review of literature. Int J Clin Cases Investig. 2011;2(6):24-36.

11. Li H, Chen V, Chen Y, Baumgartner JC, Machida CA. Herpes viruses in endodontic pathoses: association of Epstein-Barr virus with irreversible pulpitis and apical periodontitis. J Endod. 2009;35(1):23-29. doi:10.1016/j.joen.2008.09.017

12. Jakovljevic A, Andric M. Human cytomegalovirus and Epstein-Barr virus in etiopathogenesis of apical periodontitis: a systematic review. J Endod. 2014;40(1):6-15. doi:10.1016/j.joen.2013.10.001

13. ShwetaS, Prakash SK. Dentalabscess: a microbiological review. Dent Res J (Isfahan). 2013;10(5):585-591.

14. Gomes GB, Sarkis-Onofre R, Bonow ML, Etges A, Jacinto RC. An investigation of the presence of specific anaerobic species in necrotic primary teeth. Braz Oral Res. 2013;27(2):149-155.

15. Jhajharia K, Parolia A, Shetty KV, Mehta LK. Biofilm in endodontics: a review. J Int Soc Prev Community
Dent. 2015;5(1):1-12. doi:10.4103/2231-0762.151956

16. Mohammadi Z, Palazzi F, Giardino L, Shalavi S. Microbial biofilms in endodontic infections: an update review. Biomed J. 2013;36(2):59-70. doi:10.4103/2319-4170.110400

17. Drucker DB, Natsiou I. Microbial ecology of the dental root canal. Microb Ecol Health Dis. 2000;12:160-169. doi:10.4103/2319-4170.110400

18. Mistry K, Sanghvi Z, Parmar G. Endodontic pathogens-revisited. J Contemp Dent Pract. 2011;2(3):14-19.

19. Siqueira JF Jr, Rôças IN. Bacterial pathogenesis and mediators in apical periodontitis. Braz Dent J. 2007;18(4):267-280. doi:10.1590/s010364402007000400001

20. Siqueira JF Jr, Rôças IN. Distinctive features of the microbiota associated with different forms of apical periodontitis.J Oral Microbiol. 2009;10:1-12. doi:10.1590/s0103-64402007000400001

21. Yang M. Regenerative endodontics: a new treatment modality for pulp regeneration. JSM Dent. 2013;1(2):10-11.

22. Young GR, Parashos P, Messer HH. The principles of techniques for cleaning root canals. Aust Dent J. 2007;52(1):52-63.

23. Jena A, Sahoo SK, Govind S. Root canal irrigants: a review of their interactions, benefits, and limitations. Compend Contin Educ Dent. 2015;36(4):256-261.

24. Haapasalo M, Shen Y, Wang Z, Gao Y. Irrigation in endodontics. Br Dent J. 2014;216:299-303. doi:10.1038/sj.bdj.2014.204

25. Kovac J, Kovac D. Effect of irrigating solutions in endodontic therapy. Bratisl Lek Listy. 2011;112(7):410415.

26. Qian WH, Hong J, Xu PC. Analysis of the possible causes of endodontic treatment failure by inspection during apical microsurgery treatment. Shanghai Kou Qiang Yi Xue. 2015;24(2):206-209.

27. Stuart CH, Schwartz SA, Beeson TJ, Owatz CB. Enterococcus faecalis: its role in root canal treatment failure and current concepts in retreatment. J Endod. 2006;32:93-98. doi:10.1016/j.joen.2005.10.049

28. Al-Nazhan S, Al-Sulaiman A, Al-Rasheed F, Alnajjar F, Al-Abdulwahab B, Al-Badah A. Microorganism penetration in dentinal tubules of instrumented and retreated root canal walls. In vitro SEM study. Restor Dent Endod. 2014;39(4):258-264. doi:10.5395/ rde.2014.39.4.258

29. Mohammadi Z, Abbott PV. Antimicrobial substantivity of root canal irrigants and medicaments: a review. Aust Endod J. 2009;35(3):131-139. doi:10.1111/j.1747-4477.2009.00164.x

30. Saghiri MA, Delvarani A, Mehrvarzfar P, et al. The impact of $\mathrm{pH}$ on cytotoxic effects of three root canal irrigants. Saudi Dent J. 2011;23(3):149-152.

31. Bosch-Aranda ML, Canalda-Sahli C, Figueiredo R, Gay-Escoda C. Complications following an accidental sodium hypochlorite extrusion: a report of two cases. 
J Clin Exp Dent. 2012;4(3):e194-e198.

32. Nadalin MR, Perez DE, Vansan LP, Paschoala C, Souza-Neto MD, Saquy PC. Effectiveness of different final irrigation protocols in removing debris in flattened root canals. Braz Dent J. 2009;20(3):211214. doi:10.1590/s0103-64402009000300007

33. Heling I, Rotstein I, Dinur T, Szwec-Levine Y, Steinberg D. Bactericidal and cytotoxic effects of sodium hypochlorite and sodium dichloroisocyanurate solutions in vitro. J Endod. 2001;27(4):278-280. doi:10.1097/00004770-200104000-00009

34. Soares JA, Roque de Carvalho MA, Cunha Santos SM, et al. Effectiveness of chemomechanical preparation with alternating use of sodium hypochlorite and EDTA in eliminating intracanal Enterococcus faecalis biofilm. J Endod. 2010;36(5):894-898. doi:10.1016/j. joen.2010.01.002

35. Ozdemir HO, Buzoglu HD, Calt S, Stabholz A, Steinberg D. Effect of ethylenediaminetetraacetic acid and sodium hypochlorite irrigation on Enterococcus faecalisbiofilm colonization in young and old human root canal dentin: in vitro study. J Endod. 2010;36(5):842-846.

36. Iqbal A. Antimicrobial irrigants in the endodontic therapy. Int J Health Sci (Qassim). 2012; 6(2):186-192.

37. Singla MG, Garg A, Gupta S. MTAD in endodontics: an update review. Oral Surg Oral Med Oral Pathol Oral Radiol Endod. 2011;112(3):70-76. doi:10.1016/j. tripleo.2011.02.015

38. Balto HA, Shakoor ZA, Kanfar MA. Combined effect of a mixture of tetracycline, acid, and detergent, and Nisin against Enterococcus faecalis and Actinomycesviscosus biofilms. Saudi Med J. 2015;36(2):211-215. doi:10.15537/smj.2015.2.9947

39. Cauwerts K, Decostere A, De Graef EM, Haesebrouck F, Pasmans F. High prevalence of tetracycline resistance in Enterococcus isolates from broilers carrying the erm(B) gene. Avian Pathol. 2007;36(5):395-399. doi:10.1080/03079450701589167

40. Tong Z, Zhou L, Li J, Jiang W, Ma L, Ni L. In vitro evaluation of the antibacterial activities of MTAD in combination with Nisin against Enterococcus faecalis. J Endod. 2011;37:1116-1120. doi:10.1016/j. joen.2011.03.020

41. Bahador A, Pourakbari B, Bolhari B, Hashemi FB. In vitro evaluation of the antimicrobial activity of nanosilver-mineral trioxide aggregate against frequent anaerobic oral pathogens by a membraneenclosed immersion test. Biomed J. 2015;38(1):77-83.

42. Athanassiadis B, Abbott PV, Walsh LJ. The use of calcium hydroxide, antibiotics and biocides as antimicrobial medicaments in endodontics. Aust Dent J. 2007;52:S64-S82. doi:10.1111/j.1834-7819.2007. tb00527.x

43. Naenni N, Thoma K, Zehnder M. Soft tissue dissolution capacity of currently used and potential endodontic irrigants. J Endod. 2004;30:785-787. doi:10.1097/00004770-200411000-00009
44. Stuart CH, Schwartz SA, Beeson TJ, Owatz CB. Enterococcus faecalis: Its role in root canal treatment failure and current concepts in retreatment. J Endod. 2006;32:93-98. doi:10.1016/j.joen.2005.10.049

45. Huffaker SK, Safavi K, Spangberg LS, Kaufman B. Influence of a passive sonic irrigation system on the elimination of bacteria from root canal systems: a clinical study. J Endod. 2010;36(8):1315-1318. doi:10.1016/j.joen.2010.04.024

46. Mohammadi Z. Laser applications in endodontics: an update review. Int Dent J. 2009;59(1):35-46.

47. Meire MA, Coenye T, Nelis HJ, De Moor RJ. In vitro inactivation of endodontic pathogens with Nd:YAG and Er:YAG lasers. Lasers Med Sci. 2012;27(4):695701. doi:10.1007/s10103-011-0940-Z

48. Vaarkamp J, ten Bosch JJ, Verdonschot EH. Propagation of light through human dental enamel and dentine. Caries Res. 1995;29(1):8-13. doi:10.1159/000262033

49. da Costa Ribeiro A, Nogueira GE, Antoniazzi JH, Moritz A, Zezell DM. Effects of diode laser (810 nm) irradiation on root canal walls: thermographic and morphological studies. J Endod. 2007;33(3):252-255. doi:10.1016/j.joen.2006.09.002

50. Kaiwar A, Usha HL, Meena N, Ashwini P, Murthy CS. The efficiency of root canal disinfection using a diode laser: in vitro study. Indian J Dent Res. 2013;24(1):1418. doi:10.4103/0970-9290.114916

51. Bago I, Plečko V, GabrićPandurić D, Schauperl Z, Baraba A, Anić I. Antimicrobial efficacy of a highpower diode laser, photo-activated disinfection, conventional and sonic activated irrigation during root canal treatment. Int Endod J. 2013;46(4):339347. doi:10.1111/j.1365-2591.2012.02120.x

52. Meire MA, De Prijck K, Coenye T, Nelis HJ, De Moor RJ. Effectiveness of different laser systems to kill Enterococcus faecalis in aqueous suspension and in an infected tooth model. Int Endod J. 2009;42(4):351359. doi:10.1111/j.1365-2591.2008.01532.x

53. Kreisler M, Kohnen W, Beck $M$, et al. Efficacy of $\mathrm{NaOCI} / \mathrm{H} 2 \mathrm{O} 2$ irrigation and GaAlAs laser in decontamination of root canals in vitro. Lasers Surg Med. 2003;32:189-196. doi:10.1002/lsm.10148

54. Pozza DH, Fregapani PW, Xavier CB, Weber JB, Oliveira MG. CO(2), Er: YAG and Nd:YAG lasers in endodontic surgery. J Appl Oral Sci. 2009;17(6):596599. doi:10.1590/s1678-77572009000600011

55. Benedicenti S, Cassanelli C, Signore A, Ravera G, Angiero F. Decontamination of root canals with the gallium-aluminum-arsenide laser: an in vitro study. Photomed Laser Surg. 2008;26:367-370.

56. Jafari A, Shahabi S, Chiniforush N, Shariat A. Comparison of the shear bond strength of resin modified glass ionomer to enamel in bur-prepared or lased teeth (Er:YAG). J Dent (Tehran). 2013;10(2):119123.

57. George R, Meyers IA, Walsh LJ. Laser activation of endodontic irrigants with improved conical laser 
fiber tips for removing smear layer in the apical third of the root canal. J Endod.2008;34(12):1524 -1527.

58. de Groot SD, Verhaagen B, Versluis M, Wu M-K, Wesselink PR, van der Sluis LW. Laser-activated irrigation within root canals: Cleaning efficacy and flow visualization. Int Endod J. 2009;42(12):10771083. doi:10.1111/j.1365-2591.2009.01634.x

59. Peters OA, Bardsley S, Fong J, Pandher G, DiVito E. Disinfection of root canals with photon-initiated photoacoustic streaming. J Endod. 2011;37(7):10081012. doi:10.1016/j.joen.2011.03.016

60. DiVito E, Peters OA, Olivi G. Effectiveness of the erbium:YAG laser and new design radial and stripped tips in removing the smear layer after root canal instrumentation. Lasers Med Sci. 2012;27(2):273-280.

61. DiVito EE, Colonna MP, Olivi G. The photoacoustic efficacy of an Er:YAG laser with radial and stripped tips on root canal dentin walls: an SEM evaluation. $J$ Laser Dent. 2011;19(1):156-161.

62. Pedullà E, Genovese C, Campagna E, Tempera G, Rapisarda E. Decontamination efficacy of photoninitiated photoacoustic streaming (PIPS) of irrigants using low-energy laser settings: an ex vivo study. Int Endod J. 2012;45(9):865-870.

63. Soukos NS, Goodson JM. Photodynamic therapy in the control of oral biofilms. Periodontol. 2000. 2011;55(1):143-166. doi:10.1111/j.16000757.2010.00346.x

64. Parker S. The use of diffuse laser photonic energy and indocyanine green photosensitizer as an adjunct to periodontal therapy. Br Dent J. 2013; 215(4):167-171. doi:10.1038/sj.bdj.2013.790

65. Rajesh S, Koshi E, Philip K, Mohan A. Antimicrobial photodynamic therapy: An overview. I Indian Soc Periodontol. 2011;15(4):323-327.

66. Konopka K, Goslinski T. Photodynamic therapy in dentistry. J Dent Res. 2007;86(8):694-707. doi:10.1177/154405910708600803

67. Seghatchian J, Struff WG, Reichenberg S. Main Properties of the THERAFLEX MB-Plasma System for Pathogen Reduction. Transfus Med Hemother. 2011;38(1):55-64. doi:10.1159/000323786

68. Sridharan G, Shankar AA. Toluidine blue: a review of its chemistry and clinical utility. J Oral Maxillofac Pathol. 2012;16(2):251-255. doi:10.4103/0973029x.99081

69. Nikaido H. Molecular Basis of Bacterial Outer Membrane Permeability Revisited. Microbiol Mol Biol Rev. 2003;67(4):593-656.

70. Wainwright $M$, Giddens RM. Phenothiazinium photosensitisers: choices in synthesis and application. Dyes Pigm. 2003;57:245-257. doi:10.1016/s01437208(03)00021-4

71. Ilanchelian $\mathrm{M}$, Ramaraj R. Binding In teractions of Toluidine Blue $\mathrm{O}$ with Escherichia coli DNA: Formation of Bridged Structure. I Fluoresc. 2011;21:1439-1453. doi:10.1007/s10895-010-0829-4

72. Prento P. A contribution to the theory of biological staining based on the principles for structural organization of biological macromolecules. Biotech Histochem. 2001;76:137-161. doi:10.1080/ bih.76.3.137.161

73. Fekrazad R, Khoei F, Hakimiha N, Bahador A. Photoelimination of Streptococcus mutans with two methods of photodynamic and photothermal therapy. Photodiagnosis Photodyn Ther. 2013;10(4):626-631.

74. George S, Hamblin MR, Kishen A. Uptake pathways of anionic and cationic photosensitizers into bacteria. Photochem Photobiol Sci. 2009;8(6):788-795.

75. Crivello JV, Bulut U. Curcumin: a naturally occurring long-wavelength photosensitizer for diaryliodonium salts. J Polym Sci A Polym Chem. 2005;43(21):52175231. doi:10.1002/pola.21017

76. Aggarwal BB, Sundaram C, Malani N, Ichikawa H. Curcumin: the Indian solid gold. Adv Exp Med Biol. 2007;595:1-75. doi:10.1007/978-0-387-46401-5_1

77. Dovigo LN, Pavarina AC, Ribeiro AP, et al. Investigation of the photodynamic effects of curcumin against Candida albicans. Photochem Photobiol. 2011;87(4):895-903. doi:10.1111/j.17511097.2011.00937.x

78. Araújo NC, Fontana CR, Bagnato VS, Gerbi ME. Photodynamic antimicrobial therapy of curcumin in biofilms and carious dentine. Lasers Med Sci. 2014;29(2):629-635. doi:10.1007/s10103-013-1369-3

79. Tegos GP, Hamblin MR. Phenothiazinium antimicrobial photosensitizers are substrates of bacterial multidrug resistance pumps. Antimicrob Agents Chemother. 2006;50(1):196-203. doi:10.1128/ aac.50.1.196-203.2006

80. Salva KA. Photodynamic therapy: unapproved uses, dosages or indications. Clin Dermatol. 2002;20(5):571581. doi:10.1016/s0738-081x(02)00266-3

81. Biel MA. Photodynamic therapy in head and neck cancer. Curr Oncol Rep. 2002;4:87-96.

82. Grant WE, Hopper C, Speight PM, Bown SG. Photodynamic therapy, an effective, but non selective treatment for superficial cancers of the oral cavity. Int J Cancer. 1997;71:937-942.

83. Takasaki AA, Aoki A, Mizutani K, et al. Application of antimicrobial photodynamic therapy in periodontal and peri-implant diseases. Periodontol. 2000. 2009;51:109-140. doi:10.1111/j.16000757.2009.00302.x

84. Ochsner M. Photodynamic therapy in squamous cell carcinoma. J Photochem Photobial B. 2001;52:42-48.

85. Sharman WM, Allen CM, Van Lier JE. Photodynamic therapeutics: Basic principles and clinical applications. Drug Discov Today. 1999;4(11):507-517.

86. Moan J, Berg K. The photodegradation of porphyrins in cells can be used to estimate the lifetime of singlet oxygen. Photochem Photobiol B. 1991;53:549-553.

87. Cieplik F, Tabenski L, Buchalla W, Maisch T. Antimicrobial photodynamic therapy for inactivation of biofilms formed by oral key pathogens. Front Microbiol. 2014;5:405. doi:10.3389/fmicb.2014.00405 
88. Ochsner M. Photophysical and Photobiological processes in the photodynamic therapy of tumors. $J$ Photochem Photobiol B. 1997;39(1):1-18. doi:10.1016/ s1011-1344(96)07428-3

89. Kishen A, Shi Z, Shrestha A, Neoh KG. An investigation on the antibacterial and antibiofilm efficacy of cationic nanoparticulates for root canal disinfection. J Endod. 2008;34(12):1515-1520. doi:10.1016/j.joen.2008.08.035

90. Xiu-jun Fu, Yong Fang, Min Yao. Antimicrobial photodynamic therapy for methicillin-resistant Staphylococcus aureusinfection. Biomed Res Int. 2013;2013:159157. doi:10.3389/fmicb.2014.00405

91. Oleinick NL, Morris RL, Belichenko I. The role of apoptosis in response to photodynamic therapy: what, where, why, and how. Photochem Photobiol Sci. 2002;1(1):1-21. doi:/10.1039/b108586g

92. Kharkwal GB, Sharma SK, Huang YY, Dai T, Hamblin MR. Photodynamic therapy for infections: clinical applications. Lasers Surg Med. 2011;43(7):755-767.

93. Minnock A, Vernon DI, Schofield J, Griffiths J, Parish $\mathrm{JH}$, Brown SB. Mechanism of uptake of a cationic water-soluble pyridinium zinc phthalocyanine across the outer membrane of Escherichia coli. Antimicrob Agents Chemother. 2000;44(3):522-527. doi:10.1128/ aac.44.3.522-527.2000

94. de Melo WC, Avci P, de Oliveira MN, et al. Photodynamic inactivation of biofilm: taking a lightly colored approach to stubborn infection. Expert Rev Anti Infect Ther. 2013;11(7):669-693. doi:10.1586/14 787210.2013 .811861

95. Chrepa V, Kotsakis GA, Pagonis TC, Hargreaves KM. The effect of photodynamic therapy in root canal disinfection: a systematic review. J Endod. 2014;40:891-898. doi:10.1016/j.joen.2014.03.005

96. Gursoy H, Ozcakir-Tomruk C, Tanalp J, Yilmaz S. Photodynamic therapy in dentistry: a literature review. Clin Oral Investig. 2013;17(4):1113-1125.

97. Paiva SS, Siqueira JF Jr, Rôças IN, et al. Clinical antimicrobial efficacy of NiTi rotary instrumentation with $\mathrm{NaOCl}$ irrigation, final rinse with chlorhexidine and interappointment medication: a molecular study. Int Endod J. 2013;46(3):225-233. doi:10.1111/j.13652591.2012.02111.x
98. Neelakantan P, Cheng CQ, Mohanraj R, Sriraman P, Subbarao C, Sharma S. Antibiofilm activity of three irrigation protocols activated by ultrasonic, diode laser or Er:YAG laser in vitro. Int Endod J. 2015;48(6):602-610. doi:10.1111/iej.12354

99. Moslemi N, Soleiman-Zadeh Azar P, Bahador $\mathrm{A}$, et al. Inactivation of aggregatibacter actinomycetemcomitans by two different modalities of photodynamic therapy using Toluidine blue $\mathrm{O}$ or Radachlorin as photosensitizers: an in vitro study. Lasers Med Sci. 2015;30(1):89-94. doi:10.1007/ s10103-014-1621-5

100. George S, Kishen A. Photophysical, photochemical, and photobiological characterization of methylene blue formulations for light-activated root canal disinfection. J Biomed Opt. 2007;12(3):034029. doi:10.1117/1.2745982

101. Bouilaguet S, Wataha JC, Zapata O, Campo M, Lange N, Schrenzel J. Production of reactive oxygen species from photosensitizers activated with visible light sources available in dental offices. Photomed Laser Surg. 2010;28(4):519-525. doi:10.1016/j. pdpdt.2014.04.003

102. Silva TC, Pereira AF, Buzalaf MA. Diverse outcomes of photodynamic antimicrobial chemotherapy on five Enterococcus faecalis strains. Photodiagnosis Photodyn Ther. 2014;11:283-289. doi:10.1016/j. pdpdt.2014.04.003

103. Bonsor SJ, Nichol R, Reid TM, Pearson GJ. An alternative regimen for root canal disinfection. Br Dent J. 2006 22;201(2):101-105. doi:10.1038/ sj.bdj. 4813819

104. Siddiqui SH, Awan KH, Javed F. Bactericidal efficacy of photodynamic therapy against Enterococcus faecalis in infected root canals: a systematic literature review. Photodiagnosis Photodyn Ther. 2013;10(4):632-643.

105. Tennert C, Drews AM, Walther V, et al. Ultrasonic activation and chemical modification of photosensitizers enhances the effects of photodynamic therapy against Enterococcus faecalis root-canal isolates. Photodiagnosis Photodyn Ther. 2015;12(2):244-251. doi:10.1016/j.pdpdt.2015.02.002 